\title{
PENINGKATAN HASIL BELAJAR SUBTEMA KERAGAMAN SUKU BANGSA DAN AGAMA DI NEGERIKU MELALUI MODEL MIND MAPPING
}

\author{
Parindra Mismoyo ${ }^{1}$, Tri Murti ${ }^{2}$, Esti Untari ${ }^{3}$ \\ parindra1@gmail.com ${ }^{1}$,tmurti@gmail.com ${ }^{2}$, unesti@gmail.com ${ }^{3}$ \\ Mahasiswa PGSD, FIP, Universitas Negeri Malang ${ }^{1}$ \\ Dosen PGSD FIP Universitas Negeri Malang ${ }^{23}$
}

\begin{abstract}
Abstrak: Hasil belajar siswa rendah disebabkan motivasi belajar rendah dan pembelajaran berpusat pada guru. Tujuan dilakukannya penelitian ini adalah untuk memberikan variasi pembelajaran agar dapat tercapai hasil belajar yang maksimal. Jenis penelitian tindakan kelas dengan 4 tahap yaitu perencanaan, pelaksanaan, pengamatan, dan refleksi. Hasil penelitian menunjukkan peningkatan aktivitas guru sebesar $100 \%$ kriteria sangat baik, aktivitas siswa sebesar 92,5\% kriteria sangat baik dan hasil belajar yaitu aspek sikap terdapat 2 aspek tuntas, aspek keterampilan terdapat 32 siswa tuntas, dan aspek pengetahuan sebesar $90 \%$ kriteria baik. Dapat disimpulkan bahwa penerapan model Mind Mapping dapat meningkatkan aktivitas dan hasil belajar.
\end{abstract}

Kata kunci: peningkatan hasil belajar, aktivitas siswa, model mind mapping

\section{IMPROVEMENT OF LEARNING OUTCOMES IN SUBTEMA KERAGAMAN SUKU BANGSA DAN AGAMA DI NEGERIKU THROUGH MIND MAPPING MODEL}

\begin{abstract}
Student learning outcomes are low due to low learning motivation and teachercentered learning. The purpose of this study is to provide a variety of learning so that maximum learning outcomes can be obtained. Type of classroom action research with 4 stages, namely planning, implementation, observation, and reflection. The results showed an increase in teacher activity by $100 \%$ criteria very well, student activities amounted to $92.5 \%$ criteria very good and learning outcomes namely attitude aspects there were 2 complete aspects, aspects of skills there were 32 students completed, and knowledge aspects of $90 \%$ criteria good. It can be concluded that the application of the Mind Mapping model can improve activity and learning outcomes.
\end{abstract}

Keywords: improvement of learning outcomes, student activity, mind mapping model 
Parindra, Tri, Esti. Peningkatan Hasil Belajar Subtema...

PENDAHULUAN

Berdasarkan hasil observasi yang dilakukan terhadap proses pembelajaran pada siswa kelas IV SDN Karangtengah 2 Kota Blitar, terdapat permasalahan yaitu hasil belajar siswa masih rendah, rendahnya motivasi belajar siswa serta peran siswa di dalam pembelajaran masih kurang. Menurut Majid (2016:89) pembelajaran tematik memiliki karakteristik yaitu kegiatan pembelajaran berpusat pada siswa.

Permasalahan disebabkan oleh beberapa hal dalam proses pembelajaran yaitu guru dalam proses pembelajaran sering mengunakan metode ceramah, penugasan dan tanya jawab. Guru belum mencoba pembelajaran dengan menggunakan model pembelajaran tertentu, belum melakukan monitoring kegiatan siswa selama pembelajaran. Siswa kurang tertarik pada pelajaran hal ini terlihat dari sikap siswa ketika guru sedang menjelaskan materi ada beberapa siswa yang ramai.

Pembelajaran PPKn hendaknya lebih menekankan kepada konsep ilmunya sehingga transfer ilmu dapat terjadi secara optimal, serta pembelajaran PPKn hendaknya sampai pada tingkat menekankan aspek sikap sehingga siswa dapat menyiapkan perannya di masa depan (Susanto, 2016:230). Namun yang terjadi di lapangan menunjukkan hal yang berbeda dari yang telah dikemukakan oleh para ahli. Sering kali pembelajaran di SD menggunakan metode ceramah, penugasan dan tanya jawab. Tentu ini terjadi kesenjangan, dimana peran serta siswa didalam pembelajaran kurang serta nilai sikap dalam proses pembelajaran juga kurang dimunculkan. Berdasarkan tahap pratindakan yang dilakukan diperoleh hasil bahwa dari 32 siswa kelas IV yang mencapai atau melebihi nilai KKM berjumlah 11 siswa dan 21 siswa lainnya mendapat nilai kurang dari KKM. Nilai KKM yang telah ditentukan sebesar 75 .

Permasalahan tersebut dapat diperbaiki dengan menerapkan model pembelajaran yang bervariasi, agar menimbulkan minat belajar pada siswa dalam mengikuti pelajaran. Menurut Shoimin (2016:1) inovasi pembelajaran merupakan suatu yang penting dan hendaknya dilakukan guru agar pembelajaran lebih interaktif dan bermakna. Model pembelajaran yang memudahkan dalam mengingat materi, meningkatkan kreatifitas siswa, dan meningkatkan keaktifan siswa yang akan diterapkan yaitu pembelajaran dengan model Mind Mapping.

Menurut Shoimin (2016:106) berikut adalah langkah-langkah dalam menerapkan model Mind Mapping yaitu, (1) guru menyampaikan tujuan pembelajaran yang ingin dicapai oleh guru, (2) guru menyajikan materi seperti yang dilakukan pada pembelajaran biasa, (3) guru membentuk siswa menjadi beberapa kelompok, (4) guru menginstruksikan kepada salah 
Parindra, Tri, Esti. Peningkatan Hasil Belajar Subtema... seorang dari siswa untuk menceritakan materi yang baru dia diterima dari penjelasan guru dan pasangannya mendengar sambil membuat catatan hal yang penting dari penjelasan tersebut, kemudian berganti peran. Begitu pula kelompok lainnya, (5) seluruh siswa secara bergantian menyampaikan hasil wawancaranya dengan pasangannya, (6) guru menjelaskan kembali materi yang sekiranya belum dipahami oleh siswa, (7) kesimpulan/penutup.

Tujuan dari dilakukannya penelitian ini adalah untuk memberikan variasi model pembelajaran dalam upaya untuk meningkatkan hasil belajar siswa kelas 4 SDN Karangtengah 2 Kota Blitar. Karena berdasarkan temuan masalah dilapangan menunjukkan bahwa hasil belajar siswa yang rendah disebabkan karena guru belum melakukan variasi model pembelajaran dan cenderung tetap setiap harinya.

Berdasarkan permasalahan di atas, maka tujuan dari penelitian adalah untuk menerapkan model Mind Mapping dalam upaya meningkatkan hasil belajar pada subtema "keragaman suku bangsa dan agama di negeriku" pada siswa kelas IV SDN karangtengah 2 Kota Blitar. Peningkatan hasil belajar dengan penerapan model Mind Mapping pada siswa kelas IV SDN Karangtengah 2 Kota Blitar.

\section{METODE}

Pendekatan penelitian ini adalah pendekatan kualitatif. Pendekatan penelitian ini merupakan cara yang digunakan untuk meneliti kondisi objek alamiah, peran peneliti sebagai instrumen kunci, teknik pengumpulan data dilakukan secara gabungan, analisis data bersifat induktif dan lebih menekankan pada makna (Sugiyono, 2010:8).

Jenis penelitian yang digunakan merupakan penelitian tindakan kelas (PTK). Menurut Arikunto (2015:1) penelitian tindakan kelas adalah penelitian yang menjelaskan hubungan sebab-akibat dari perlakuan yang telah diberikan, sekaligus memaparkan dari proses awal pemberian perlakuan sampai dengan dampak dari pemberian perlakuan tersebut. Pada penelitian ini menggunakan model penelitian yang dikembangkan oleh Arikunto (2015:42). Penelitian ini dilaksanakan sebanyak 2 siklus, dalam 1 siklus ada empat tahapan yang harus dilakukan, yaitu (1) perencanaan, (2) pelaksanaan, (3) pengamatan, dan (4) refleksi.

Data yang digunakan dalam penelitian meliputi data proses dan data hasil belajar siswa pada subtema "keragaman suku bangsa dan agama di negeriku" menggunakan model Mind Mapping. Jenis data yang dikumpulkan meliputi data observasi dan data hasil belajar. 
Parindra, Tri, Esti. Peningkatan Hasil Belajar Subtema...

Data observasi meliputi aktivitas guru dan aktivitas siswa selama kegiatan pembelajaran. Data hasil belajar siswa meliputi aspek sikap, keterampilan, dan pengetahuan.

Sumber data dari penelitian ini adalah guru dan siswa kelas IV SDN Karangtengah 2 Kota Blitar. Teknik pengumpulan data penelitian ini menggunakan beberapa teknik yaitu observasi, wawancara, tes, catatan lapangan, dan dokumentasi. Pengumpulan data tersebut bertujuan untuk mendapatkan data selama penelitian berlangsung.

Analisis data meliputi mengelompokkan data berdasarkan variabel dan jenis responden, mentabulasi data berdasarkan variabel dari seluruh responden, menyajikan data pada tiap variabel yang diteliti, melakukan perhitungan untuk menjawab rumusan masalah, dan melakukan perhitungan untuk menguji hipotesis yang diujikan (Sugiyono, 2010: 147).

Analisis data, evaluasi, dan refleksi dilaksanakan dari awal hingga akhir penelitian. Analisis diawali dengan pengumpulan data dari hasil wawancara, observasi, tes evaluasi, dokumentasi, dan catatan lapangan.

Teknik analisis data yang digunakan dalam penelitian ini adalah reduksi data, penyajian data, dan penarikan kesimpulan. Hasil data observasi aktivitas guru, aktivitas siswa, sikap, keterampilan dan pengetahuan siswa selama pembelajaran dihitung berdasarkan rumus.

Penarikan kesimpulan siswa dikelompokkan antara siswa yang mendapatkan nilai di atas rata-rata dengan kategori tuntas dan belum tuntas belajar, baik secara individu maupun klasikal. Siswa dikatakan tuntas secara individu apabila nilainya mencapai $\geq 75 \mathrm{KKM}$, sedangkan siswa yang belum tuntas apabila mendapat nilai di bawah KKM. Ketuntasan klasikal dapat tercapai apabila $80 \%$ siswa dalam satu kelas telah mencapai nilai $\geq 75$.

\section{HASIL PENELITIAN}

\section{Siklus 1}

Hasil observasi aktivitas guru dalam menerapkan model Mind Mapping pada siklus I adalah sebagai berikut.

Tabel 1 Akumulasi Presentase Aktivitas Guru Siklus I

\begin{tabular}{|l|c|c|}
\hline \multicolumn{1}{|c|}{ Siklus I } & \multicolumn{2}{c|}{ Pertemuan } \\
\hline & $\mathbf{1}$ & $\mathbf{2}$ \\
\hline Jumlah aspek yang tampak dilaksanakan & 12 & 14 \\
\hline Persentase (\%) aktivitas guru & $85 \%$ & $100 \%$ \\
\hline Rata-rata Siklus I & \multicolumn{2}{|c|}{$92,5 \%$} \\
\hline
\end{tabular}

Berdasarkan tabel 1 tersebut dapat dilihat bahwa persentase skor yang didapat dari aktivitas guru pertemuan I adalah $85 \%$ dan termasuk predikat B. hal ini disebabkan karena 
Parindra, Tri, Esti. Peningkatan Hasil Belajar Subtema...

guru belum melaksanakan seluruh langkah-langkah Mind Mapping. Kemudian persentase skor untuk pertemuan II adalah $100 \%$ dan termasuk dalam predikat A. Rata-rata persentase skor aktivitas guru pada siklus I adalah 92,5\% dan termasuk dalam predikat A dengan kriteria sangat baik. Dari hasil observasi aktivitas guru pada pertemuan I terdapat 12 deskriptor yang tampak dan pertemuan II terdapat 14 deskriptor yang tampak. Hal ini menunjukkan bahwa ada peningkatan dalam aktivitas guru pada siklus I.

Data hasil observasi aktivitas siswa dalam menerapkan model Mind Mapping pada siklus I dapat dilihat pada tabel berikut.

Tabel 2 Akumulasi Presentase Aktivitas Siswa Siklus I

\begin{tabular}{|c|c|c|c|c|}
\hline No & Siklus I & Skor maksimal & Skor & Persentase \\
\hline 1 & Pertemuan I & 256 & 205 & $80 \%$ \\
\hline 2 & Pertemuan II & 256 & 211 & $82 \%$ \\
\hline \multicolumn{3}{|c|}{ Rata-rata persentase } & $81 \%$ \\
\hline \multicolumn{3}{|c|}{ Predikat } & Baik \\
\hline
\end{tabular}

Berdasarkan tabel 2 dapat dilihat bahwa aktivitas siswa pada siklus I pertemuan I yaitu $80 \%$. Kemudian mengalami peningkatan pada pertemuan II yaitu $82 \%$ dan mengalami peningkatan sebesar 2\%. Dari hasil rekapitulasi diperoleh rata-rata persentase siklus I sebesar $81 \%$ dan termasuk dalam predikat B dengan kriteria baik.

\section{Nilai Sikap}

Nilai sikap merupakan nilai yang diperoleh dari pengamatan pada siswa selama kegiatan pembelajaran berlangsung dengan menggunakan model mind mapping. Di bawah ini adalah tabel penilaian sikap pada pembelajaran yang berlangsung di kelas IV SDN Karangtengah 2 Kota Blitar.

Tabel 3 Rekapitulasi Penilaian Sikap Siswa pada Siklus I

\begin{tabular}{|l|c|c|c|c|}
\hline \multirow{2}{*}{ Siklus I } & \multicolumn{4}{|c|}{ Aspek Penilaian Sikap } \\
\cline { 2 - 5 } & Percayadiri & Disiplin & Tanggungjawab & Peduli \\
\cline { 2 - 5 } & Muncul & Muncul & Muncul & Muncul \\
\hline Pertemuan I & 10 & 22 & 25 & 7 \\
\hline Pertemuan II & 13 & 28 & 26 & 9 \\
\hline Jumlah & 23 & 50 & 51 & 8 \\
\hline $\begin{array}{l}\text { Rata-rata kemunculan pada } \\
\text { siklus I }\end{array}$ & 11 & 25 & 25 & \\
\hline
\end{tabular}

Berdasarkan tabel 3, dapat disimpulkan bahwa pada semua sikap yang dinilai mengalami kenaikan baik dari sikap percaya diri, disiplin, tanggungjawab maupun peduli. Pada sikap percaya diri pada pertemuan I terdapat 10 siswa meningkat menjadi 13 siswa pada pertemuan II, kemudian sikap disiplin semula terdapat 22 siswa naik menjadi 28 siswa pada pertemuan II. Sikap tanggung jawab pada pertemuan I muncul 25 siswa meningkat menjadi 26 siswa dan sikap peduli yang semula muncul 7 siswa meningkat menjadi 9 siswa. Sikap 
Parindra, Tri, Esti. Peningkatan Hasil Belajar Subtema... yang dominan muncul pada siklus I adalah sikap disiplin dan tanggungjawab yaitu dengan rata-rata kemunculan 25 siswa. Sikap yang paling sedikit muncul pada siklus I adalah sikap peduli dengan rata-rata kemunculan sebanyak 8 siswa.

\section{Nilai Pengetahuan}

Nilai pengetahuan siswa diperoleh dari hasil tes evaluasi selama pembelajaran pada siklus I. Data nilai siswa dipaparkan dalam tabel berikut.

Tabel 4 Rekapitulasi Penilaian Pengetahuan Siswa pada Siklus I

\begin{tabular}{|l|c|c|c|c|}
\hline \multirow{2}{*}{ Siklus I } & \multirow{2}{*}{ Skor } & \multirow{2}{*}{ Rata-rata } & \multicolumn{2}{c|}{ Ketuntasan } \\
\cline { 4 - 5 } & & & Tuntas & Belum Tuntas \\
\hline Pertemuan I & 2230 & 69,7 & $13(40,6 \%)$ & $19(59,4 \%)$ \\
\hline Pertemuan II & 2415 & 75,5 & $20(62,5 \%)$ & $12(47,5 \%)$ \\
\hline Rata-rata nilai & \multicolumn{3}{|c|}{72,6} \\
\hline \multicolumn{2}{|l|}{ Ketuntasan klasikal siklus I } & $22,5 \%$ \\
\hline
\end{tabular}

Berdasarkan tabel 4 di atas dapat diketahui bahwa pada pertemuan I dan pertemuan II mengalami peningkatan dari 13 siswa yang tuntas menjadi 20 siswa yang tuntas. Pada pertemuan I diperoleh rata-rata 69,7 dengan persentase ketuntasan 40,6\% (13 siswa yang sudah tuntas). Pada pertemuan II diperoleh rata-rata 75,5 dengan persentase ketuntasan sebesar 62,5\% (20 siswa yang sudah tuntas). Persentase ketuntasan kelas pada siklus I sebesar $62,5 \%$ dengan predikat $\mathrm{C}$ (termasuk kriteria cukup).

\section{Nilai Keterampilan}

Nilai keterampilan yang diperoleh siswa selama pembelajaran siklus I dengan model Mind Mapping. Berikut adalah rekapitulasi nilai ketrampilan siswa.

Tabel 5 Rekapitulasi Penilaian Keterampilan Siswa Siklus I

\begin{tabular}{|c|c|c|c|c|}
\hline \multirow{2}{*}{ Siklus I } & \multicolumn{4}{|c|}{ Nilai } \\
\cline { 2 - 5 } & $\mathbf{8 6 - 1 0 0}$ & $\mathbf{7 1 - 8 5}$ & $\mathbf{5 6}-\mathbf{7 0}$ & $\leq \mathbf{5 5}$ \\
\hline Pertemuan I & - & 23 & 9 & - \\
\hline Pertemuan II & - & 24 & 8 & - \\
\hline Jumlah & - & 47 & 17 & - \\
\hline Rata-rata kemunculan pada siklus I & - & 23 & 8 & - \\
\hline
\end{tabular}

Berdasarkan tabel 5 belum ada siswa yang memperoleh nilai antara 86 - 100 dan tidak ada yang mendapat nilai $\leq 55$. Pada siklus I nilai ketrampilan yang paling banyak diperoleh siswa adalah antara nilai 71 - 85 termasuk predikat B sebanyak 23 siswa pada pertemuan I dan mengalami kenaikan pada pertemuan II yaitu diperoleh 24 siswa, dengan rata-rata kemunculan siklus I sebanyak 25 siswa. Nilai antara 56 - 70 termasuk predikat C dengan kriteria cukup pada pertemuan I sebanyak 9 siswa dan 5 siswa pada pertemuan II dengan rata-rata kemunculan pada siklus I sebanyak 7 siswa. 
Parindra, Tri, Esti. Peningkatan Hasil Belajar Subtema...

Siklus 2

\section{Observasi Aktivitas Guru}

Data hasil observasi aktivitas guru dalam menerapkan model Mind Mapping pada siklus II adalah sebagai berikut.

Tabel 6 Akumulasi Presentase Aktivitas Guru Siklus II

\begin{tabular}{|c|c|c|}
\hline Siklus II & \multicolumn{2}{|c|}{ Pertemuan } \\
\hline & $\mathbf{1}$ & $\mathbf{2}$ \\
\hline Jumlah aspek yang tampak dilaksanakan & 14 & 14 \\
\hline Persentase (\%) aktivitas guru & $100 \%$ & $100 \%$ \\
\hline Rata-rata Siklus I & \multicolumn{2}{|c|}{$100 \%$} \\
\hline
\end{tabular}

Berdasarkan hasil observasi tersebut dapat dilihat bahwa persentase skor yang didapat dari aktivitas guru pertemuan I adalah 100\%. Kemudian persentase skor untuk pertemuan II adalah 100\%. Rata-rata persentase skor aktivitas guru pada siklus II adalah $100 \%$ dan termasuk dalam predikat baik. Dari hasil observasi aktivitas guru pada pertemuan I terdapat 14 deskriptor yang tampak dan pertemuan II terdapat 14 deskriptor yang tampak. Hal ini menunjukkan bahwa guru sudah melaksanakan pembelajaran sesuai dengan langkah model Mind Mapping dan sudah melaksanakan rekomendasi dari refleksi siklus I.

\section{Observasi Aktivitas Siswa}

Data hasil observasi aktivitas siswa dalam menerapkan model mind mapping pada siklus II dapat dilihat pada tabel berikut.

Tabel 7 Akumulasi Presentase Aktivitas Siswa Siklus II

\begin{tabular}{|c|c|c|c|c|}
\hline No & Siklus II & Skor maksimal & Skor & Persentase \\
\hline 1 & Pertemuan I & 256 & 229 & $89,5 \%$ \\
\hline 2 & Pertemuan II & 256 & 237 & $92,6 \%$ \\
\hline \multicolumn{3}{|c|}{ Rata-rata persentase } & $91,5 \%$ \\
\hline \multicolumn{2}{|c|}{ Predikat } \\
\hline
\end{tabular}

Berdasarkan tabel di atas dapat dilihat bahwa aktivitas siswa pada siklus II pertemuan I yaitu $89.5 \%$. Kemudian mengalami peningkatan pada pertemuan II diperoleh rata-rata persentase sebesar 92,6\% dan mengalami peningkatan sebesar 3,1\%. Dari hasil rekapitulasi tabel 7 diperoleh rata-rata persentase sebesar $91,5 \%$ dan termasuk dalam predikat A.

\section{Nilai Sikap}

Nilai sikap merupakan nilai yang diperoleh dari pengamatan pada ssiswa selama kegiatan pembelajaran berlangsung dengan menggunakan model mind mapping. Di bawah ini 
Parindra, Tri, Esti. Peningkatan Hasil Belajar Subtema... adalah tabel penilaian sikap pada pembelajaran yang berlangsung di kelas IV SDN Karangtengah 2 Kota Blitar.

Tabel 8 Rekapitulasi Penilaian Sikap Siswa pada Siklus II

\begin{tabular}{|c|c|c|c|c|}
\hline \multirow{2}{*}{ Siklus II } & \multicolumn{4}{|c|}{ Aspek Penilaian Sikap } \\
\cline { 2 - 5 } & Percayadiri & Disiplin & Tanggungjawab & Peduli \\
\cline { 2 - 5 } & Muncul & Muncul & Muncul & Muncul \\
\hline Pertemuan I & 16 & 30 & 28 & 10 \\
\hline Pertemuan II & 17 & 29 & 30 & 10 \\
\hline Jumlah & 33 & 59 & 58 & 10 \\
\hline $\begin{array}{c}\text { Rata-rata kemunculan pada } \\
\text { siklus II }\end{array}$ & 16 & 29 & 29 & \multirow{2}{*}{} \\
\hline
\end{tabular}

Berdasarkan tabel 8 dapat dilihat bahwa yang paling banyak muncul adalah sikap tanggung jawab dan disiplin yaitu dengan rata-rata kemunculan sebesar 29. Pada pertemuan II untuk sikap disiplin mengalami penurunan pada pertemuan II yang semula sebanyak 30 siswa menurun menjadi 29 siswa, karena ada siswa yang menunjukkan sikap kurang disiplin saat pembelajaran. Sikap tanggungjawab mengalami kenaikan pada siklus II yaitu semula sebanyak 28 siswa naik menjadi 30 siswa. Untuk sikap percaya diri mengalami kenaikan dari pertemuan I yang semula sebanyak 16 siswa naik menjadi 17 siswa dan untuk sikap peduli pada pertemuan I dan II sebanyak 10 siswa.

\section{Nilai Pengetahuan}

Nilai pengetahuan siswa diperoleh dari hasil tes evaluasi selama pembelajaran pada siklus II. Data nilai siswa dipaparkan dalam tabel berikut.

Tabel 9 Rekapitulasi Penilaian Pengetahuan Siswa pada Siklus II

\begin{tabular}{|c|c|c|c|c|}
\hline \multirow{2}{*}{ Siklus II } & \multirow{2}{*}{ Skor } & \multirow{2}{*}{ Rata-rata } & \multicolumn{2}{|c|}{ Ketuntasan } \\
\cline { 3 - 5 } & & & Tuntas & Belum Tuntas \\
\hline Pertemuan I & 2820 & 88 & $28(87,5 \%)$ & $4(12,5 \%)$ \\
\hline Pertemuan II & 2900 & 90,6 & $29(90,6 \%)$ & $3(9,4 \%)$ \\
\hline Rata-rata nilai & \multicolumn{3}{|c}{99,3} \\
\hline \multicolumn{2}{|r|}{ Ketuntasan klasikal siklus II } & \multicolumn{3}{|c}{$90,6 \%$} \\
\hline
\end{tabular}

Berdasarkan tabel di atas dapat diketahui bahwa pada pertemuan I dan pertemuan II mengalami peningkatan dari 28 siswa yang tuntas menjadi 29 siswa yang tuntas. Pada pertemuan I diperoleh rata-rata nilai sebesar 88 dengan persentase ketuntasan $87,5 \%$ (28 siswa yang sudah tuntas). Pada pertemuan II diperoleh rata-rata nilai sebesar 90,6 dengan persentase ketuntasan sebesar 90,6\% (29 siswa yang sudah tuntas). Dari hasil rekapitulasi pada tabel 4.9 diperoleh persentase ketuntasan kelas pada siklus II sebesar 90,6\% dengan predikat A. 
Parindra, Tri, Esti. Peningkatan Hasil Belajar Subtema...

Nilai Keterampilan

Nilai kertampilan yang diperoleh siswa selama pembelajaran siklus II dengan model Mind Mapping. Berikut adalah rekapitulasi nilai ketrampilan siswa.

Tabel 10 Rekapitulasi Penilaian Keterampilan Siswa Siklus II

\begin{tabular}{|c|c|c|c|c|}
\hline \multirow{2}{*}{ Siklus II } & \multicolumn{4}{|c|}{ Nilai } \\
\cline { 2 - 5 } & $\mathbf{8 6 - 1 0 0}$ & $\mathbf{7 1 - 8 5}$ & $\mathbf{5 6}-\mathbf{7 0}$ & $\leq \mathbf{5 5}$ \\
\hline Pertemuan I & - & 28 & 5 & - \\
\hline Pertemuan II & 20 & 12 & - & - \\
\hline Jumlah & 20 & 40 & 5 & - \\
\hline Rata-rata kemunculan pada siklus II & 10 & 20 & 3 & - \\
\hline
\end{tabular}

Berdasarkan tabel 10 tidak ada yang mendapat nilai dibawah atau sama dengan 55 . Sebagian besar siswa memperoleh nilai antara 71 - 85 yaitu pada pertemuan I sebanyak 23 siswa dan pertemuan II sebanyak 12 siswa dengan rata-rata kemunculan siklus II sebanyak 20 siswa. Untuk siswa yang mendapatkan nilai antara 56 - 70 ada sebanyak 5 siswa pada pertemuan I. Siswa yang mendapatkan nilai 86 - 100 hanya pada pertemuan II dengan jumlah siswa sebanyak 20. Dari hasil rekapitulasi dapat disimpulkan bahwa telah terjadi kenaikan perolehan nilai siswa yang pada pertemuan I belum ada yang mendapat nilai antara $86-100$ namun pada pertemuan II terdapat 20 siswa yang mendapat nilai antara 86 - 100 dan termasuk predikat A. si waktu, dan guru perlu melakukan bimbingan dan motivasi kepada siswa yang pasif dalam pembelajaran.

\section{PEMBAHASAN}

Penerapan model Mind Mapping pada pembelajaran subtema "keragaman suku bangsa dan agama di negeriku" dilaksanakan dalam dua siklus. Guru sudah melaksanakan pembelajaran dengan menggunakan RPP yang sudah disesuaikan dengan langkah dari model

\section{Mind Mapping.}

Permasalahan yang muncul pada siklus I antara lain siswa belum terbiasa dengan pembelajaran menggunakan model Mind Mapping, sehingga guru perlu memberikan penjelasan beberapa kali agar siswa dapat memahami langkah-langkah membuat Mind Mapping. Kemudian waktu yang digunakan untuk pembelajaran melebihi yang sudah direncanakan karena siswa sewaktu mengerjakan LKK melebihi waktu yang sudah ditentukan. Guru perlu memberi motivasi dan pendampingan pada siswa yang pasif dan tidak mau mengerjakan tugas. Guru perlu mengelola kelas lebih lanjut karena ketika guru sedang menerangkan materi ada siswa yang ramai. 


\section{Parindra, Tri, Esti. Peningkatan Hasil Belajar Subtema...}

Pada siklus II guru telah memperbaiki permasalahan yang terdapat pada siklus I. Guru sudah melakukan kegiatan pembelajaran sesuai dengan RPP yang telah disusun dengan memperhatikan permasalahan dan kekurangan yang muncul pada siklus I agar pembelajaran dapat berjalan lebih baik dan sesuai dengan perancanaan yang telah disusun. Guru sudah melakukan kegiatan pembelajaran lebih baik dari siklus I dan sesuai langkah-langkah model pembelajaran Mind Mapping. Untuk menyesuaikan alokasi waktu saat mengerjakan tugas, guru membuat kesepakatan dengan siswa dengan cara mengambil pekerjaan siswa apabila dalam mengerjakan melebihi batas yang sudah ditentukan dan guru sudah melakukan pendampingan dan memberi motivasi kepada siswa yang pasif dalam pembelajaran.

Pembelajaran yang dilakukan oleh guru pada subtema "keragaman suku bangsa dan agama di negeriku" berjalan lancar dan sesuai dengan langkah-langkah model pembelajaran Mind Mapping. Langkah-langkah model Mind Mapping seperti yang dikemukakan oleh Shoimin (2016:106). Berdasarkan hasil penelitian pada siklus I persentase skor sebesar 92,5\% dan termasuk kriteria sangat baik. Kemudian pada siklus II mengalami peningkatan persentase skor menjadi $100 \%$ dengan kriteria sangat baik. Hal ini sesuai dengan pernyataan dari Yoananda (2017) bahwa penggunaan model Mind Mapping dapat menigkatkan aktivitas guru dan mengelola pembelajaran.

Pada siklus I aktivitas siswa terdapat beberapa hambatan, yaitu masih terdapat siswa yang ramai ketika guru menjelaskan materi, masih ada sebagian siswa yang belum paham cara membuat Mind Mapping, siswa belum percaya diri saat presentasi di depan kelas, dan siswa belum aktif dalam menanggapi jawaban kelompok yang presentasi. Hal ini disebabkan karena siswa belum terbiasa dengan pembelajaran menggunakan model Mind Mapping.

Aktivitas siswa pada siklus II sudah mengalami peningkatan, yakni suasana kelas sudah lebih kondusif dan tenang, siswa sudah paham cara membuat Mind Mapping, siswa lebih percaya diri dalam menyampaikan presentasi, siswa menjadi lebih kreatif dalam membuat Mind Mapping dan sebagian siswa sudah aktif dalam menangapi jawaban kelompok yang presentasi. Hal ini disebabkan karena siswa sudah beradaptasi dengan pembelajaran menggunakan model Mind Mapping.

Peningkatan aktivitas siswa yang telah dijelaskan di atas sesuai dengan kelebihan dari model pembelajaran Mind Mapping yang dikemukakan oleh Michalko (dalam Buzan, 2005: 6), antara lain: Mambantu siswa untuk mengaktifkan kemampuan seluruh otaknya, membantu siswa untuk tetap fokus pada pokok bahasan yang ada, membantu menunjukkan hubungan 
Parindra, Tri, Esti. Peningkatan Hasil Belajar Subtema... antara bagian-bagian yang saling terpisah, memberi gambaran yang jelas pada keseluruhan materi, memungkinkan siswa mengelompokkan konsep, serta membantu siswa untuk membandingkannya. Dan juga sesuai dengan kelebihan model Mind Mapping yang dikemukakakan oleh Shoimin (2016:107) diantaranya: cara ini cepat, teknik dapat digunakan untuk mengorganisasikan ide yang muncul dalam pemikiran, proses menggambar diagram bisa memunculkan ide yang lain, dan diagram yang sudah terbentuk bisa menjadi panduan untuk menulis.

Hasil persentase skor aktivitas siswa siklus I sebesar $81 \%$ dengan kriteria baik dan meningkat pada siklus II menjadi 91,5\% dengan kriteria sangat baik. Hal ini membuktikan bahwa penerapan model Mind Mapping dapat meningkatkan keaktifan siswa, kepercayaan diri siswa, mengasah kreatifitas siswa, dan memudahkan siswa dalam memahami materi. Berdasarkan uraian di atas dapat disimpulkan bahwa adanya peningkatan aktivitas yang dilakukan oleh guru dan siswa dalam menerapkan model Mind Mapping.

Pembelajaran dengan menggunakan model Mind Mapping dilaksanakan untuk meningkatkan hasil belajar siswa, dalam tiga aspek yaitu sikap, keterampilan, dan pengetahuan. Hal ini sesuai dengan Peraturan Menteri Pendidikan dan Kebudayaan Nomor 23 Tahun 2016 tentang Standar Penilaian Pendidikan yang menyatakan bahwa penilaian hasil belajar siswa meliputi aspek sikap, pengetahuan, dan keterampilan. Oleh karena itu, penilaian hasil dan proses belajar saling berkaitan, dikarenakan hasil merupakan akibat dari suatu proses pembelajaran yang dilakukan siswa.

Pada aspek sikap pada siklus I semua aspek yang diamati (percaya diri, disiplin, tanggungjawab, dan peduli) mengalami kenaikan. Aspek sikap yang sering muncul adalah sikap disiplin dengan perolehan sebanyak 28 siswa. Untuk sikap percaya diri diperoleh sebanyak 13 siswa, kemudian sikap tanggungjawab 26 siswa dan sikap peduli sebanyak 9 siswa. Dapat dinyatakan tuntas apabila diperoleh oleh 26 siswa pada minimal 2 sikap yang diamati. Jadi dapat dinyatakan pada siklus I sudah mencapai ketuntasan klasikal. Pada siklus II aspek sikap yang diamati mengalami kenaikan daripada siklus I. Sikap percaya diri sebanyak 17 siswa, sikap disiplin sebanyak 29 siswa, sikap tanggungjawab sebanyak 30 siswa dan sikap peduli sebanyak 10 siswa. Siklus II dapat dinyatakan tuntas karena sudah melebihi target yang ditentukan.

Aspek pengetahuan pada siklus I diperoleh ketuntasan klasikal sebesar 62,5\% (20 siswa yang sudah tuntas). Kemudian mengalami peningkatan pada siklus II menjadi 90,6\%. Hal ini 
Parindra, Tri, Esti. Peningkatan Hasil Belajar Subtema... sesuai dengan peryataan dari Mehakati (2017) bahwa model Mind Mapping dapat meningkatkan hasil belajar siswa dalam ranah pengetahuan. Jadi berdasarkan ketuntasan klasikal yang telah ditentukan yaitu sebesar 80\% menurut Mulyasa (2015:143), pada siklus II dapat dinyatakan tuntas.

Aspek keterampilan pada siklus I yang mendapatkan nilai antara 71-100 yaitu sebanyak 24 siswa. Pada siklus II yang mendapatkan nilai antara 71-100 sebanyak 32 siswa. Keterampilan yang terlihat pada proses pembelajaran yang telah dilakukan siswa dapat membuat Mind Mapping dengan lebih kreatif, hal ini sesuai dengan pendapat De Porter (dalam Safitri, 2016) bahwa manfaat Mind Mapping yaitu menyenangkan, karena dalam membuat Mind Mapping, imajinasi dan kreativitas yang tertuang tidak terbatas. Jadi aspek keterampilan dapat dinyatakan tuntas apabila jumlah siswa yang memperoleh nilai antara 71100 sebanyak 26 siswa (80\%). Jadi untuk siklus II dapat dinyatakan tuntas.

Peningkatan hasil belajar yang telah dicapai siswa pada siklus I dan siklus II dikarenakan terjadinya perubahan yang dilakukan oleh guru dalam menyampaikan materi dan mengelola kelas. Proses belajar baik dari proses belajar siswa ataupun proses mengajar guru mempengaruhi hasil belajar siswa baik dalam aspek sikap, pengetahuan maupun keterampilan. Hal ini sejalan dengan pendapat yang dikemukakan oleh Woodwort (dalam Majid, 2014:28) hasil belajar merupakan perubahan tingkah laku sebagai akibat dari proses belajar. Berdasarkan hasil penelitian tersebut menujukkan bahwa selama pembelajaran diperoleh hasil belajar siswa mengalami peningkatan. Dari hasil tersebut, dapat dikatakan bahwa penggunaan model Mind Mapping pada pembelajaran pada subtema "keragaman suku bangsa dan agama di negeriku" dapat meningkatkan hasil belajar siswa kelas IV SDN Karangtengah 2 Kota Blitar.

\section{SIMPULAN}

Penerapan model Mind Mapping pada subtema "keragaman suku bangsa dan agama di negeriku"pada siswa kelas IV SDN Karangtengah 2 Kota Blitar, telah dilaksanakan sangat baik sesuai dengan langkah-langkah model Mind Mapping. Hal ini dibuktikan dengan hasil persentase skor aktivitas guru pada siklus I sebesar $81 \%$ dengan kriteria baik. Kemudian pada siklus II menjadi 100\% dengan kriteria sangat baik. Aktivitas siswa siklus I diperoleh persentase skor sebesar $81 \%$ dengan kriteria baik dan mengalami peningkatan pada siklus II menjadi 91,5\% dengan kriteria sangat baik. 


\section{Parindra, Tri, Esti. Peningkatan Hasil Belajar Subtema...}

Hasil belajar siswa pada aspek sikap siklus I diperoleh sikap yang sering muncul yaitu disiplin sebanyak 28 siswa. Kemudian meningkat pada siklus II dengan perolehan sikap yang sering muncul yaitu sikap tanggungjawab sebanyak 30 siswa. Aspek pengetahuan pada siklus I diperoleh ketuntasan klasikal sebesar 62,5\% dengan nilai rata-rata sebesar 72,6. Pada siklus II diperoleh ketuntasan klasikal sebesar 90,6\% dengan rata-rata nilai sebesar 89,3. Pada aspek keterampilan siklus I diperoleh ketuntasan klasikal sebanyak 24 siswa atau dalam persentase sebesar $75 \%$ dan belum dapat dikatakan tuntas karena belum mencapai $80 \%$ ketuntasan klasikal. Pada siklus II mengalami peningkatan dengan perolehan $32 \%$ atau dalam persentase $100 \%$ dan sudah dapat dikatakan tuntas.

\section{UCAPAN TERIMA KASIH}

Terima kasih diucapkan Penulis kepada orang tua yang telah memberikan dukungan moril maupun materiil, kepada dosen pembimbing yang telah memberikan bimbingan kepada Penulis agar terwujudnya tulisan ini dengan maksimal, kemudian kepada seluruh guru dan staf SDN 2 Karangtengah Kota Blitar yang telah memberikan tempat untuk penelitian dan juga telah memberikan dukungan demi tercapainya penelitian ini.

\section{DAFTAR RUJUKAN}

Arikunto, Suharsimi, dkk. 2015. Penelitian Tindakan Kelas. Jakarta: Bumi Aksara.

Buzan, Tony. 2005. Buku Pintar Mind Map. Jakarta: PT Gramedia Pustaka Utama.

Majid, Abdul. 2014. Pembelajaran Tematik Terpadu. Bandung: PT Remaja Rosdakarya.

Mehakati, Frederikus Umbu. 2017. Peningkatan Hasil Belajar Siswa Menggunakan (Mind Mapping) Pada Mata Pelajaran Ips Kelas V Sd. 678 Jurnal Pendidikan Guru Sekolah Dasar Edisi $\quad 7 \quad$ Tahun 2017. https://www.google.com/url/jurnal.fkip.uns.ac.id\%2Findex.php

Peraturan Menteri Pendidikan dan Kebudayaan Republik Indonesia Nomor 23 Tahun 2016 tentang Standar Penilaian Pendidikan. (Online).(https:// bsnp-indonesia.org/), diakses pada 23 April 2018

Safitri, Dyah. 2016. Penerapan Metode Mind Mapping Untuk Meningkatkan Minat Dan Hasil Belajar Ipa Siswa Kelas V Sd N Balangan 1. Jurnal Pendidikan Guru Sekolah Dasar

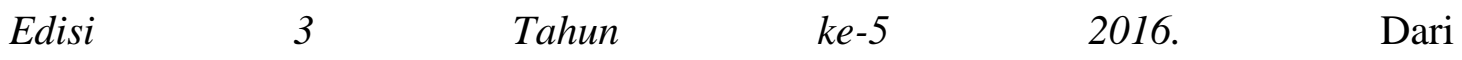
http://journal.student.uny.ac.id/ojs/index.php/pgsd/article/view/

Shoimin, Aris. 2016. 68 Model Pembelajaran Inovatif dalam Kurikulum 2013. Yogyakarta: Ar-Ruzz Media. 
Parindra, Tri, Esti. Peningkatan Hasil Belajar Subtema...

Sugiyono. 2010. Metode Penelitian Pendidikan Pendekatan Kuantitatif, Kualitatif, dan R\&D. Bandung: Alfabeta.

Susanto, Ahmad. 2016. Teori Belajar dan Pembelajaran di Sekolah Dasar. Jakarta: Prenamedia Group.

Yoananda, Devi Afriyuni. 2017. Peningkatan Pemahaman Siswa Mata Pelajaran Pkn Tentang Sistempemerintahan Melalui Metode M2m (Mind Mapping) Kelas Iv Mi Mambaul Ulum Tegalgondo Karangploso Malang. Jurnal Cakrawala Pendas Vol. 3 No.1 Edisi Januari 2017. Dari http://eprints.umm.ac.id/ 30766/ 